\title{
ARTIKELEN
}

\section{Pleidooi voor en uitwerking van een maximalistisch herstelrecht}

\author{
Jacques Claessen
}

\section{Inleiding}

In deze bijdrage wordt een lans gebroken voor een verdere operationalisering van het subsidiariteitsbeginsel via de weg van een maximalistisch herstelrecht, een herstelrecht dat niet alleen ruimte biedt voor 'vrijwillige overlegprocessen' en overeengekomen herstel, maar ook voor 'dwingende procedures' en opgelegd herstel. Getracht wordt om het maximalistische arsenaal aan herstelsancties zo concreet mogelijk te maken. Ik zal daarbij vooral bogen op werk van John Blad en Lode Walgrave dat eerder in het Tijdschrift voor Herstelrecht is verschenen. Richting het einde van deze bijdrage haal ik ook even Herman Thomas Bianchi's enige publicatie in dit tijdschrift aan. Daarmee zijn voor mij 'De Grote Drie' van het 'normatief-kritische' herstelrecht compleet.

\section{Subsidiariteit in theorie anno 2005}

Vijftien jaar geleden hield John Blad in het Tijdschrift voor Herstelrecht een pleidooi voor herstelrecht als operationalisering van het subsidiariteitsbeginsel dat de facto uit de Verlichting stamt, waarin ons strafrecht wortelt (Blad, 2005). In zijn bijdrage maakt Blad onderscheid tussen externe en interne subsidiariteit. Terwijl externe subsidiariteit ziet op het zo min mogelijk criminaliseren van ongewenst gedrag en op het zo veel mogelijk voorkomen van dergelijk gedrag langs andere wegen dan het strafrecht (sociale politiek), ziet interne subsidiariteit op het zo min mogelijk toepassen van dwangmiddelen tijdens het strafproces en het zo min mogelijk opleggen van straf in het kader van de sanctionering. Terwijl herstelgerichte praktijken die buiten het strafrecht in verschillende sociale contexten worden ingezet volgens Blad 'een uitstekende operationalisering [...] van het externe subsidiariteitsbeginsel' vormen (p. 22), kunnen herstelrecht en herstelgerichte procedures in strafzaken 'een bijdrage leveren aan een functionele, minimale sanctie' (p. 28), lees: aan de operationalisering van het interne subsidiariteitsbeginsel. Het herstelrechtelijke denken en doen maken, zo kan worden geconcludeerd, een operationalisering van het subsidiariteitsbeginsel mogelijk en daarmee een terugkeer naar het strafrecht en de toepassing van straffen daarbinnen als ultimum remedium. Waarom het strafrecht laatste redmiddel dient te zijn? Simpelweg omdat straf - in de klassieke betekenis van intentionele leedtoevoeging - 
een kwaad is dat uitsluitend mag worden toegepast indien dat echt noodzakelijk is (p. 15; zie ook: Claessen, 2010, hoofdstukken 3 en 4).

\section{Subsidiariteit in praktijk anno 2020}

Hoe staat het vijftien jaar later in Nederland met de operationalisering van het subsidiariteitsbeginsel via herstelrechtelijke weg? Mijns inziens kan gerust worden gesteld dat in de tussenliggende periode heel wat is gebeurd. Allereerst is het aantal herstelgerichte praktijken in de civil society aanzienlijk toegenomen alsook de toepassing ervan. Het gaat hierbij onder andere om conflicten tussen burgers in buurten/wijken, scholen, bedrijven, sportclubs, kerken en andere maatschappelijke organisaties. Herstelgerichte praktijken in de civil society zijn erop gericht om burgers zelf actief te betrekken bij de de-escalatie en oplossing van deze conflicten. In dit verband kan bijvoorbeeld worden gedacht aan buurtbemiddeling, jongerenrechtbanken en de Vreedzame Wijk-aanpak.

Daarnaast dient te worden gewezen op de Halt-afdoening in het jeugdstrafrecht (art. 77e Sr). Deze 'deelname aan een project' duurt maximaal twintig uren en geschiedt door de dader op vrijwillige basis. Succesvolle deelname leidt ertoe dat een aangifte of proces-verbaal van bevindingen niet aan de officier van justitie wordt toegezonden en dat 'een strafblad' wordt voorkomen. De Halt-afdoening wordt in toenemende mate herstelgericht vormgegeven en bestaat thans uit het uitvoeren van werk- en/of leeropdrachten die een link hebben met het gepleegde delict, het schrijven van een excuusbrief aan het slachtoffer en de mogelijkheid van een herstelgesprek met het slachtoffer. Inmiddels is een pilot voorbereid, waarin de Halt-afdoening ook aangeboden zal worden aan adolescente daders (18- tot 23-jarigen). Overigens lijkt het mij goed om ook na te denken over de vormgeving en invoering van een soortgelijke diversiemogelijkheid voor volwassen daders van lichte strafbare feiten.

Voorts hebben inmiddels ook herstelrecht en herstelgerichte procedures in strafzaken een vlucht genomen. Dat is mede gebeurd onder invloed van regelgeving en aanbevelingen vanuit de Europese Unie respectievelijk de Raad van Europa. Sinds 2007 bestaat in Nederland de mogelijkheid dat slachtoffers en daders los van (lees: voor, naast of na) de strafzaak met elkaar in gesprek gaan over de gepleegde misdaad en de gevolgen daarvan. Deze dialoog is primair gericht op emotioneel en relationeel herstel. In eerste instantie werd gesproken van slachtoffer-dadergesprekken, tegenwoordig van (herstel)bemiddeling. Herstelrecht als onderdeel van het strafrecht c.q. de strafzaak heeft in 2011 een wettelijke basis gekregen met de invoering van artikel $51 \mathrm{~h}$ Wetboek van Strafvordering (Sv). Na een succesvolle pilot met mediation in Amsterdam in 2013 en een aantal eveneens succesvolle mediationpilots verspreid over het land in 2015-2016 is mediation in strafzaken in 2017 in het hele land ingevoerd. Bij mediation gaat het niet alleen om emotioneel en relationeel herstel; slachtoffers en daders kunnen tijdens een mediation ook afspraken maken over herstel van de door het strafbare feit veroorzaakte (im)materiële schade. Deze afspraken worden neergelegd in een overeenkomst, 
waarmee de officier van justitie dan wel de rechter ingevolge artikel 51h lid $2 \mathrm{~Sv}$ rekening dient te houden in het kader van de afdoening/sanctionering (Claessen et al., 2018; Claessen \& Roelofs, 2020). Terwijl Blad anno 2005 waarschuwde voor het mogelijk in het gedrang raken van het sepotbeleid wegens de invoering van de OM-afdoening (p. 24), kan anno 2020 met enige opluchting worden gemeld dat een meerderheid van de mediations in strafzaken plaatsvindt op OM-niveau en dat het grootste deel van de succesvolle mediations op dat niveau eindigt in een sepot onder de voorwaarde dat de door partijen in het kader van de mediation gemaakte afspraken worden nageleefd.

Kunnen we nu - gezien de hiervoor genoemde ontwikkelingen - spreken van een optimale operationalisering van het subsidiariteitsbeginsel? Het antwoord luidt mijns inziens ontkennend, waarbij ik in het onderstaande enkel zal focussen op de interne subsidiariteit. ${ }^{1}$ Immers, hoewel - anders dan Blad in 2005 voorstelt geen categorisering heeft plaatsgevonden wat betreft 'herstelbare delicten' (p. 27-28) en in principe dus alle strafbare feiten in aanmerking komen voor herstelgerichte procedures als mediation, moet niettemin worden onderkend dat het aantal mediations in strafzaken vooralsnog bescheiden is (ca. 850 stuks per jaar, waarvan ruim $80 \%$ succesvol). Daarnaast dient te worden vastgesteld dat van Blads ideale - want meest volledig - herstelgerichte procedure, namelijk 'het herstelgericht groepsoverleg' oftewel de herstelconferentie, vooralsnog niet veel is terechtgekomen, ook al bestaan er inmiddels 'mediations XL' waarbij niet alleen slachtoffer en dader betrokken zijn maar ook ondersteunende personen (Claessen et al., 2018; Claessen \& Roelofs, 2020). Kortom: ik denk dat we zeker tevreden mogen zijn wat er in Nederland op herstelrechtelijk gebied sinds 2005 is gerealiseerd, maar er kan zeker nog meer - en dus ook wat betreft de operationalisering van het subsidiariteitsbeginsel.

\section{Maximalistisch herstelrecht}

Dat meer bestaat niet slechts uit meer diversiemogelijkheden en meer mediations en herstelconferenties. Met Lode Walgrave huldig ik de opvatting dat, ook wanneer 'vrijwillige overlegprocessen' om tot herstel te komen niet mogelijk blijken nadat een misdaad is gepleegd, het hersteldoel blijft staan. Na misdaad dient (zo veel mogelijk) herstel van (feitelijke en morele) schade plaats te vinden. Ongeveer tien jaar geleden hield Walgrave in het Tijdschrift voor Herstelrecht een pleidooi voor een maximalistische visie op herstelrecht en ondanks kritiek hierop, is hij - terecht - bij zijn standpunt gebleven (Walgrave, 2009 en 2010). ${ }^{2}$ Hij schrijft: 'Een beperking tot vrijwillige overlegprocessen sluit herstelrecht op in de marges van het systeem [...], een aanhangsel bij het mainstream strafrecht' en 'De voor-

1 Wanneer in het onderstaande wordt gesproken van (het) subsidiariteit(sbeginsel), dan wordt daarmee (het) interne subsidiariteit(sbeginsel) bedoeld.

2 Dit pleidooi hield hij al veel eerder buiten het Tijdschrift voor Herstelrecht, zie onder meer: Walgrave, 2008. Tegenwoordig spreekt Walgrave overigens liever van 'een consequente visie op herstelrecht' of 'een consequent herstelrecht' (zie zijn column in dit nummer van het tijdschrift). 
rang voor overlegprocessen is ingegeven door het feit dat ze meestal een hoger niveau van herstel tot stand kunnen brengen. Maar indien dat niet mogelijk is, dan moeten ook dwingende verplichtingen met het oog op reparatie worden overwogen' (p. 2033; zie ook: Walgrave, 2010: 25 en 33). De vraag is echter of met het binnenhalen van dwingende herstelverplichtingen (is hier sprake van een pleonasme?) herstel niet verwordt tot straf.

\section{Straf en herstel}

Volgens Walgrave bevat straf drie cumulatieve, constitutieve elementen: leed, intentie en het verband tussen een gepleegde misdaad en de intentionele leedtoevoeging (p. 21). Welbeschouwd definieert Walgrave straf op klassieke wijze en om zowel ethische als functionele redenen wijst hij intentionele leedtoevoeging en daarmee straf - in ieder geval als a priori reactie op misdaad - af. Met een herstelverplichting is in de visie van Walgrave dan ook geen sprake van straf, want de intentie om aan de dader leed toe te voegen ontbreekt; het doel is immers herstel. Dat een dergelijke verplichting voor de dader met leed gepaard gaat, is waarschijnlijk en wellicht onvermijdelijk, maar dat is iets anders dan bedoeld. Niet de pijnvolle beleving van degene die tot herstel verplicht wordt, maar de herstellende bedoeling van degene die de herstelverplichting oplegt, is doorslaggevend: 'Ethische oordelen worden uitgesproken over intenties' (p. 22). In reactie op Walgrave stelt Blad zich op het standpunt dat bij opgelegde herstelgerichte sancties wél sprake is van straf:

'Er is geen bestraffing van de dader wanneer de rechter voorstellen van de dader (liefst na overleg met de door hem gedupeerden) sanctioneert, maar wel wanneer hij weliswaar reparatieve, maar toch pijnlijke, sancties oplegt aan een niet-meewerkende verdachte (na veroordeling die dan ook nodig zal zijn)' (Blad, 2009: 59; zie ook: Blad, 2011).

Kortom: in de ogen van Blad is vrijwillig overeengekomen herstel geen straf, opgelegd herstel daarentegen wel. Zelf schrijf ik hierover in het Tijdschrift voor Herstelrecht:

'Sancties [kunnen] een tweevoudig gewelddadig karakter [...] hebben: (1) wanneer sprake is van intentionele leedtoevoeging (ter vergelding en/of preventie) en (2) wanneer zij tegen of ongeacht de wil van de dader worden opgelegd. Is aan beide voorwaarden voldaan, dan is sprake van een strafsanctie. Met betrekking tot herstelsancties geldt dat ook zij een (enkelvoudig) gewelddadig karakter kunnen hebben, namelijk wanneer zij worden afgedwongen [waarvoor in een maximalistisch herstelrecht ruimte is, JC]. Om die reden worden ook deze sancties door verscheidene rechtsgeleerden als strafsancties

3 Waar in deze bijdrage enkel paginanummers worden genoemd, betreft het verwijzingen naar Walgrave, 2009. 
gekwalificeerd. Het meest moreel (en effectief?) zijn sancties die geen intentionele leedtoevoeging bevatten én die (met behulp van voorlichting, aanmoediging of overreding) vrijwillig door de dader worden aanvaard. Van laatstgenoemde sancties kan moeilijk worden gezegd dat zij een strafkarakter hebben' (Claessen, 2012: 48). ${ }^{4}$

Op de vraag of opgelegd herstel al dan niet als straf dient te worden gekwalificeerd omdat er sprake is van dwang, worden derhalve verschillende antwoorden gegeven. Zelf ben ik geneigd de kant van Walgrave te kiezen, omdat in mijn ogen dwang alleen een sanctie nog niet tot straf maakt. Ware dat wel het geval, dan zouden ook maatregelen die tegen de wil van de dader (kunnen) worden opgelegd, waaronder de terbeschikkingstelling met dwangverpleging, de ontneming van het wederrechtelijk verkregen voordeel en de schadevergoeding aan het slachtoffer, als straf moeten worden gekwalificeerd - wat niet het geval is. Wat hier ook van zij, in ieder geval is duidelijk dat opgelegd herstel zich bevindt tussen enerzijds intentionele leedtoevoeging en anderzijds vrijwillig overeengekomen herstel. Voor mij geldt niet alleen dat vrijwillig overeengekomen herstel ethisch (en functioneel) gezien beter is dan opgelegd herstel, maar ook dat opgelegd herstel ethisch (en functioneel) gezien beter is dan intentionele leedtoevoeging.

\section{Vergelding en omgekeerde vergelding}

Evenals straf definieert Walgrave vergelding op klassieke wijze, wat logisch is, want straffen is vergelden en beide concepten kunnen derhalve niet wezenlijk iets anders inhouden (Claessen, 2010, hoofdstuk 3). Walgrave omschrijft vergelding als het herstellen van 'een onevenwicht [...] door aan de dader een leed op te leggen dat proportioneel wordt geacht aan het leed dat hij-/zijzelf heeft veroorzaakt' (p. 27). En aangezien Walgrave intentionele leedtoevoeging om ethische en functionele redenen afwijst, wijst hij niet alleen straf maar ook vergelding af. Toch ligt ook in herstelrecht de nadruk op het herstellen van de door de gepleegde misdaad ontstane disbalans. Echter, herstellen bestaat hier niet uit het de dader met gelijke munt betaald zetten, maar uit het primair door de dader zo goed mogelijk laten herstellen van de veroorzaakte schade (p. 27; zie ook: Zehr, 2015: 75). Het toegebrachte leed wordt derhalve niet verdubbeld, er wordt juist getracht het leed weg te nemen. In de woorden van Walgrave: 'Herstelrecht kan worden gezien als een vorm van omgekeerde vergelding' en 'Herstelrecht blijkt [...] een vorm van vergeldend recht te kunnen zijn, maar dan in een opbouwende betekenis, ten

4 De vraag kan worden gesteld of sancties die onder invloed van voorlichting, aanmoediging of overreding door de dader worden aanvaard, door deze vrijwillig worden aanvaard. Geen enkele keuze vindt plaats in een vacuüm; er zijn altijd externe factoren die van invloed zijn op iemands keuzevorming. Zo bezien is geen enkele keuze vrijwillig te noemen. Niettemin vind ik dat bij voorlichting, aanmoediging en overreding gesproken kan worden van vrijwillig aanvaarde sancties, zolang de dader de facto een keuze heeft, waarbij de keuze is gebaseerd op een innerlijke afweging van interne en externe factoren. Dat is in ieder geval niet zo, wanneer een sanctie topdown aan de dader wordt opgelegd zonder dat rekening wordt gehouden met diens keuze. 
dienste van de kwaliteit van het sociale leven' (p. 20; zie ook: Walgrave, 2010: 29). Kortom: herstellen is omgekeerd vergelden. Anders gezegd: straf is vergelding van kwaad met kwaad, herstel is vergelding van kwaad met goed (Claessen, 2010 en 2018). Mijns inziens kan hieraan worden toegevoegd dat, wanneer de dader vrijwillig ervoor kiest om de schade te herstellen, er méér sprake is van omgekeerde vergelding dan wanneer de dader hiertoe wordt gedwongen; niettemin is mijns inziens ook bij opgelegd herstel sprake van omgekeerde vergelding - en niet van vergelding.

\section{Opgelegd herstel: schadevergoedingsmaatregel en taakstraf}

Wanneer overeengekomen herstel middels 'vrijwillige overlegprocessen' onmogelijk blijkt, komt in een maximalistisch herstelrecht door de officier van justitie dan wel de rechter opgelegd herstel in beeld. Walgrave noemt als voorbeelden 'materiele restitutie of compensatie voor het slachtoffer, het betalen van boetes [zelf zou ik meer neutraal spreken van een geldsom, JC] ten voordeel van een slachtofferfonds of een ander werk van sociaal nut [en] gemeenschapsdienst' (p. 20). Hendrik Kaptein die in zekere zin een maximalistisch herstelrecht aanhangt, nu hij vergelding interpreteert als (schade)vergoeding, ${ }^{5}$ deinst er in het Tijdschrift voor Herstelrecht niet voor terug om dwangarbeid als 'hoofdstraf' te poneren (p. 53). Kwalificaties als 'boete', 'dwangarbeid' en 'hoofdstraf' laten al zien hoe lastig het is om dwingende herstelverplichtingen die onvermijdelijk met leed gepaard gaan, te (onder)scheiden van straf die intentionele leedtoevoeging inhoudt. Blad waarschuwt terecht dat ervoor moet worden gewaakt dat 'de herstelverplichting als niets anders dan een alternatieve straf zal worden gezien' (Blad, 2009: 57). Niettemin ligt het in mijn visie voor de hand om bij opgelegd herstel primair te denken aan de verplichting tot schadevergoeding aan het slachtoffer en tot het verrichten van onbetaalde herstelwerkzaamheden jegens het slachtoffer en/of de gemeenschap. Het huidige sanctiearsenaal overziend zou kunnen worden gesproken van de oplegging van een schadevergoedingsmaatregel en een taakstraf.

\section{Van taakstraf naar herstelverplichting}

Opvallend daarbij is dat bij de eerstgenoemde sanctie sprake is van een maatregel en bij de als tweede genoemde sanctie van een straf. In theorie én praktijk heeft de taakstraf - anders dan de volledig reparatoire schadevergoedingsmaatregel niet alleen een (vaak symbolisch) reparatoir, maar ook een vergeldend karakter. Uitsluitend de term 'taakstraf' verruilen voor 'de verplichting tot het verrichten van onbetaalde herstelwerkzaamheden' zou niet meer dan een toedekking van het vergeldende karakter van deze inhoudelijk ongewijzigde sanctie opleveren. Om de

5 Hij schrijft: 'Het antwoord op het kwaad is niet het nieuwe kwaad van het leed van de straf, maar de eigenwerkzaamheid van daders om zo veel mogelijk goed te maken wat zij hebben misdaan. Leed voor daders is dan een voor slachtoffers niet onwelkom bijverschijnsel, als gevolg van het soms harde - herstelwerk' (Kaptein, 2008: 49). 
taakstraf echt om te vormen tot een herstelverplichting is het mijns inziens sowieso noodzakelijk om het reparatieve karakter ervan zo veel mogelijk te vergroten en (daarmee tegelijkertijd) het weinig constructieve vergeldende karakter ervan zo veel mogelijk te verkleinen. Dat kan door bij de bepaling van de inhoud van de onbetaalde herstelwerkzaamheden - veel meer dan thans het geval is aansluiting te zoeken bij de gepleegde misdaad en/of het slachtoffer daarvan (Claessen, 2019); McCold \& Wachtel spreken in dit verband van related community service als een deels herstelgerichte sanctie (2003). Echter, uiteindelijk zal voor deze 'omvorming' vooral een bewustzijnsverandering nodig zijn wat betreft het sanctioneren van misdaad: gaat het om intentionele leedtoevoeging óf (schade)herstel dat waarschijnlijk en wellicht onvermijdelijk met leed gepaard gaat?

Ter omvorming van de taakstraf tot een herstelverplichting zou er mijns inziens tevens naar moeten worden gestreefd de conflictpartijen zo veel mogelijk zelf de inhoud van de onbetaalde herstelwerkzaamheden te laten bepalen (Claessen, 2020). De aanpak zal noodzakelijkerwijs evenwel anders zijn in zaken met bekennende verdachten dan in zaken met ontkennende of zwijgende verdachten. In zaken met een bekennende verdachte ${ }^{6}$ waarin de officier van justitie dan wel de rechter voornemens is ${ }^{7}$ een taakstraf op te leggen, zou voortaan moeten worden onderzocht of de partijen in het kader van een mediation (tussen dader en slachtoffer) of een herstelconferentie (tussen dader, slachtoffer en gemeenschap) zo veel mogelijk zelf de inhoud van de te verrichten onbetaalde herstelwerkzaamheden willen bepalen. De officier van justitie dan wel de rechter zou de afspraken of het herstelplan vervolgens al dan niet kunnen fiatteren - en eventueel aanvullen. In zaken met een ontkennende of zwijgende verdachte bestaat deze onderzoeksplicht vanzelfsprekend niet - mede gezien de onschuldpresumptie. In die zaken is het aan de officier van justitie dan wel de rechter om de inhoud van de te verrichten onbetaalde herstelwerkzaamheden te bepalen. Een andere mogelijkheid is in dat geval dat na een onherroepelijke veroordeling waarbij sprake is van oplegging van een taakstraf, de partijen in de executiefase alsnog worden uitgenodigd om zo veel mogelijk zelf de inhoud van de onbetaalde herstelwerkzaamheden te bepalen. Het hier geponeerde idee is rudimentair en dient te worden uitgewerkt, maar de ratio erachter is het combineren van de herstelgerichte procedure (mediation/ herstelconferentie) met de herstelgerichte inhoud (onbetaalde herstelwerkzaamheden). Een tweefasenproces zou de realisering van dit idee aanzienlijk vergemakkelijken, maar voor Nederland lijkt dit een gepasseerd station.

Tot slot wil ik in deze paragraaf over herstelverplichtingen wijzen op een helaas wat onbekende en bij mijn weten (daarom ook) weinig gebruikte sanctie uit het bijzondere strafrecht. In artikel 8 sub c van de Wet op de economische delicten

6 En waarin zich geen bewijsproblemen voordoen, dat wil zeggen: er is sprake van voldoende (rechtmatig verkregen) wettig en overtuigend bewijs.

7 Zie ook paragraaf 9 over vrijheidsbeneming om te zien in welke gevallen de officier van justitie dan wel de rechter idealiter hiertoe voornemens zouden moeten zijn - bezien vanuit een maximalistisch herstelrecht. 
(WED) wordt als maatregel genoemd 'het opleggen van de verplichting tot verrichting van hetgeen wederrechtelijk is nagelaten, tenietdoening van hetgeen wederrechtelijk is verricht en verrichting van prestaties tot het goedmaken van een en ander, alles op kosten van de veroordeelde, voor zover de rechter niet anders bepaalt'. Een dergelijke herstelsanctie hoort mijns inziens ook thuis in het commune strafrecht, zeer zeker wanneer dat in maximalistisch herstelrechtelijke richting wordt hervormd.

\section{$9 \quad$ Vrijheidsbeneming}

Hoe zit het in een maximalistisch herstelrecht met vrijheidsbeneming? Walgrave geeft een duidelijk antwoord op deze vraag, wanneer hij een soort piramidemodel bespreekt ter zake van 'een consequent op herstel gericht rechtssysteem':

'De brede basis ervan wordt gevormd door ruime mogelijkheden tot vrijwillig (eventueel gerechtelijk gesuperviseerd) overleg. [...] Vervolgens wordt een reeks variaties voorzien van gerechtelijke dwang, waarin gerichtheid op herstel consequent de voorrang krijgt, of toch minstens een plaats krijgt. De (kleine) top van de piramide is voor de gevallen waarin veiligheidsoverwegingen de opsluiting van bepaalde daders noodzakelijk maakt' (Walgrave 2009, p. 35).

Voor vrijheidsbeneming is dus enkel plaats, indien de dader een onverantwoord gevaar vormt voor de openbare veiligheid - ter preventie dus. Voor vrijheidsbeneming op grond van vergelding is geen ruimte. De vrijheidsbeneming die een maximalistisch herstelrecht toelaat, staat mijns inziens niet alleen in het teken van maatschappijbeveiliging op korte termijn middels opsluiting, maar ook maatschappijbeveiliging op langere termijn middels het zo veel mogelijk wegnemen van de gevaarlijkheid van de dader. In het kader van duurzaam herstel wordt immers ook aandacht besteed aan de oorzaken die tot de misdaad hebben geleid (Zehr, 2015: 40). ${ }^{8}$ Welbeschouwd krijgt de vrijheidsbeneming het karakter van een maatregel en daarmee zou het huidige onderscheid tussen de gevangenisstraf en de terbeschikkingstelling met dwangverpleging komen te vervallen; overblijven zou de vrijheidsbeneming met behandeling (zie in dit verband ook: Jongeneel \& Claessen, 2018).

Het voorgaande impliceert dat in gevallen waarin geen sprake is van een gevaarlijkheid van de dader die tot vrijheidsbeneming noopt én waarin geen vrijwillig hersteloverleg mogelijk is, opgelegd herstel de aangewezen sanctie is. ${ }^{9}$ Het voorgaande impliceert mijns inziens voorts dat, wanneer de dader geen of onvoldoende medewerking verleent aan een hem opgelegde herstelsanctie als het betalen van een som geld aan het slachtoffer of een slachtofferfonds, dit niet mag leiden tot vervangende hechtenis, maar wel tot het verrichten van vervangende

8 Zie ook paragraaf 10 over resocialisatie en rehabilitatie.

9 Tot op zekere hoogte overeenkomend met Kapteins 'hoofdstraf' dwangarbeid. 
herstelwerkzaamheden (waarvan de opbrengst wordt gebruikt ter betaling van de som geld). Vervangende vrijheidsbeneming lijkt mij in een maximalistisch herstelrecht enkel een rol te mogen spelen, wanneer een dader de hem opgelegde herstelwerkzaamheden (anders dan het betalen van een som geld) niet of niet naar behoren uitvoert en blijft weigeren dat te doen.

\section{Elektronische thuisdetentie}

Walgrave schrijft: 'Ik zie geen enkele reden om de prioriteit voor herstel op te geven in geval van zware feiten of recalcitrante daders. Ook in deze gevallen blijft intentionele leedtoevoeging ethisch verwerpelijk en ineffectief' (Walgrave, 2010: 32). Niettemin lijkt Walgrave te onderkennen dat in dergelijke gevallen straf in de klassieke zin van het woord noodzakelijk kan zijn 'voor het emotionele herstel van de slachtoffers en/of van de openbare rust' (Walgrave, 2009: 23). Hoewel het apriorisme van het herstel dan niet wordt verlaten (er wordt immers gestreefd naar emotioneel herstel), lijkt wel sprake van 'een synthese van herstelrecht met een instrumentele straftheorie', waarbij de straf 'een middel, naast andere, in het herstelproces' wordt (Walgrave, 2009: 23). Zelf ziet Walgrave - het mag geen verbazing wekken - weinig heil in straf als middel tot herstel. Toch komt in de huidige rechtspraktijk bij ernstige misdaden al snel vrijheidsbeneming als vergeldende sanctie (lees: straf) in beeld. Omdat herstelrecht mijns inziens niet alleen gaat over het herstellen van aangerichte schade, maar ook over het voorkomen van nieuwe schade, waarbij ook gedacht moet worden aan detentieschade, zou ik willen pleiten voor de invoering van elektronische thuisdetentie als zelfstandige sanctie. ${ }^{10}$

Deze sanctie valt lastig te rijmen met een puur herstelgericht sanctierecht dat ontdaan is van ieder spoor van vergelding, máár omdat ons rechtssysteem gezien de condition humaine nooit geheel ontdaan zal kunnen zijn van vergelding (Claessen, 2018) én omdat elektronische thuisdetentie minder schadelijk is dan reguliere detentie (Claessen, 2015), verdient zij de voorkeur. Met elektronische detentie verliest een dader niet zijn woning, werk en/of wederhelft en raakt hij niet 'besmet door doorgewinterde criminelen'. De recidivecijfers na elektronische thuisdetentie liggen dan ook significant lager dan die na reguliere detentie, zodat nieuwe slachtoffers en dientengevolge nieuwe schade worden voorkomen. Bovendien kan bij een aangeklede vorm van elektronische detentie ruimte (een 'vrijplaats') worden gecreëerd om actief aan herstel te werken. Daarbij kan worden gedacht aan herstel van de dader jegens zichzelf middels scholing, training en therapie alsook aan herstel jegens het slachtoffer en de gemeenschap, bijvoorbeeld in de vorm van bemiddeling of mediation (in het kader waarvan tevens afspraken

10 Pleitbezorgers van een humaan en effectief strafrecht niet zijnde herstelrechtsdenkers hebben het waarschijnlijk gemakkelijker om te pleiten voor de invoering van elektronische detentie. Toch vind ik de invoering ervan ook verdedigbaar vanuit het perspectief van een maximalistisch herstelrecht. 
kunnen worden gemaakt over contact- en gebiedsverboden ${ }^{11}$ ). In plaats van enkel top-downcontrole door de overheid kan bij deze sanctie ook worden gedacht aan een meer bottom-up vormgegeven controle middels COSA-achtige projecten. ${ }^{12}$ Kortom: 'huisarrest' heeft als vergaande vorm van vrijheidsbeperking de voorkeur boven 'de cel', tenzij er openbare veiligheidsredenen zijn die tot vrijheidsbeneming nopen.

\section{Resocialisatie en rehabilitatie}

Zoals uit het voorgaande blijkt, zie ik ook resocialisatie en rehabilitatie van de dader als wezenlijke doelstellingen binnen herstelrecht. Zonder herstel van de dader zelf wordt herstel door de dader jegens het slachtoffer en de gemeenschap bovendien erg lastig. In die zin sluit ik aan bij wat Blad stelt: 'Een herstelrecht dat aan de wensen en behoeften van slachtoffers tegemoet wil komen, moet zich ook de vraag naar de preventie van toekomstige victimisering aantrekken' (Blad, 2009: 54). Hoewel 'hulpverlening of (her)opvoeding van de dader' volgens Walgrave ondergeschikt is aan het hersteldoel, vindt hij wel dat vermeden moet worden 'dat aan de dader nog bijkomende schade wordt toegebracht' en 'dat hulpverlening of (her)opvoeding van de dader [...] perfect met het herstel [kan] worden gecombineerd' (Walgrave, 2010: 31). In het kader van de resocialisatie en rehabilitatie van de dader pleit ik voor een terugkeer van de leerstraf als zelfstandige sanctie in het volwassenenstrafrecht, waarbij deze het karakter dient te krijgen van een herstelgerichte leeropdracht - gekoppeld aan de gepleegde misdaad en/ of het slachtoffer daarvan.

\section{Herstel van feitelijke en morele schade}

Volgens Blad is herstelrecht - evenals strafrecht - gericht op normhandhaving (Blad, 2005: 25). Elders schrijft hij 'dat het sanctieconcept van het herstelrecht in beginsel reparatoir van aard is, maar dat dit reparatieve beter niet louter feitelijk [...] dient te worden opgevat, maar eerder normatief en moreel van aard' (Blad, 2011). Evenals bij Walgrave ligt in deze bijdrage de nadruk op herstel van feitelijke schade, máár daarin besloten ligt mijns inziens ook (het belang van) het herstel van morele schade, herstel van de door misdaad geschonden norm. Wat in ieder geval vaststaat, is dat 'de straf [...] niet nodig [is] om een normovertreding klaar en duidelijk te verwerpen'; wel daarvan uitgaan 'is een ethisch onverteerbaar vooroordeel' (Walgrave, 2009: 26 en 28).

11 Top-down zijn contact- en gebiedsverboden in een dergelijk geval mogelijk, wanneer de rechter een vrijheidsbeperkende maatregel ex art. 38v Sv oplegt (naast elektronische detentie).

12 COSA staat voor Cirkels voor Ondersteuning, Samenwerking en Aanspreekbaarheid en is een project van Reclassering Nederland en Avans Hogeschool Expertisecentrum Veiligheid dat zich op de re-integratie van zedendaders richt. Bij COSA werken vrijwilligers, beroepskrachten (zoals reclassering, hulpverleners en politie) samen om zedendelinquenten onder begeleiding terug te laten keren in de maatschappij. 


\section{Sanctionering in het misdaadrecht}

In 2012 schreef ik:

'De vraag is of een rechtsstelsel dat ruimte biedt voor: (1) vrijwillig aanvaarde constructieve sancties [...] niet in de marge maar als primum remedium; (2) niet vrijwillig aanvaarde herstelsancties en maatregelen; en (3) als ultimum remedium afgedwongen intentionele leedtoevoeging ter vergelding en/of preventie, de benaming strafrecht verdient. [...] Mijns inziens vormt niet strafrecht (met zijn straffen) maar misdaadrecht (met zijn sancties) een huis voor meerdere theorieën over hoe op misdaad dient te worden gereageerd' (Claessen, 2012: 48).

In de woorden van Herman Bianchi:

'Het is [...] verkeerd om te spreken van "strafrecht", want het zou beter zijn dit deel van het recht als "misdaadrecht" te betitelen [...]. De term "strafrecht" suggereert immers dat er op misdaad altijd met "straf" gereageerd moet worden, wat dus principieel en moreel onaanvaardbaar is, omdat er zoveel andere mogelijkheden zijn. De term "strafrecht" danken we aan Napoleon, "code pénal", want daarvoor sprak men in Nederland van "criminele ordonnantiën”' (Bianchi, 2008: 4-5).

Anno 2020 sta ik hier nog helemaal achter, zij het dat ik nu beter zie dat er een 'grijs gebied' zit tussen de sanctiecategorieën 2 en 3 . Bezien vanuit een maximalistisch herstelrecht is het de opgave om in het kader van deze sancties (waaronder de taakstraf en elektronische thuisdetentie) ervoor te zorgen dat de herstelcomponent (omgekeerde vergelding) zo groot mogelijk wordt gemaakt en de strafcomponent (vergelding) zo klein mogelijk.

\section{Programma Changing Justice Gears}

Dit jaar is het driejarige programma Changing Justice Gears van start gegaan. In dat programma werken onder meer Restorative Justice Nederland en Universiteit Maastricht samen met wetenschappers en praktijkmensen uit het strafrecht in twee projecten. Terwijl project 1 focust op een uitvoerigere, betere sanctiemotivering, ziet project 2 op het ontwikkelen van alternatieven voor de korte vrijheidsstraf. Het betreft geen nieuwe onderzoeksthema's. Vernieuwend is dat we in dit project direct aansluiting zoeken bij de strafrechtelijke werkvloer en de burger. Middels denktanks, simulaties en living labs wordt gestreefd naar een bottomupbenadering. Tegelijkertijd zal ook in politiek Den Haag worden gelobbyd. 
In project 2 kan worden gedacht aan meer zaken afdoen via vrijwillige overlegprocessen als mediation en de herstelconferentie. ${ }^{13}$ Voorts kan worden gedacht aan momenteel lopende projecten waarin partijen actief worden betrokken bij de aanpak van hun eigen $\mathrm{zaak}^{14}$ en aan pilots met maatschappelijk effectieve rechtspraak. ${ }^{15}$ Natuurlijk staan in dit project ook de (herstelgerichte) taakstraf (beter: 'de verplichting tot het verrichten van onbetaalde herstelwerkzaamheden') en de elektronische thuisdetentie centraal als alternatieven voor detentie. Een maximalistisch herstelrecht helpt bij het zoeken naar betekenisvolle alternatieven voor vrijheidsbeneming, zij het dat ook pleitbezorgers van een humaan en effectief strafrecht niet zijnde herstelrechtsdenkers vanzelfsprekend zinvolle input hiervoor kunnen leveren (denk bijvoorbeeld aan elektronische detentie).

In project 1 helpt een maximalistisch herstelrecht ook. Zo zou een sanctiemotivering die expliciet aandacht besteedt aan sanctiedoelen, inclusief herstel, voor de hand liggen, maar wellicht ook het aanbrengen van een rangorde (beter: subsidiariteit) binnen deze sanctiedoelen. Anno 2005 merkte Blad op dat 'de strafvordering nu [tendeert] naar een bloedeloze boekhoudkundige praktijk', waarbij impliciet is gekozen voor 'de afschrikking als strafdoel, al dan niet in combinatie met vergeldingsnoties, ten detrimente van doelstellingen als speciale preventie door resocialisatie' (Blad, 2005: 16-17). Deze uitspraak heeft niets aan actualiteitswaarde verloren. Het is opnieuw tijd voor fundamentele vragen: wat willen we nu eigenlijk bereiken met de sanctionering nadat een misdaad is gepleegd? Hoe kan dat het beste worden bereikt? En ontleend aan Walgraves betoog: zijn vergelding en herstel aparte sanctiedoelen of kunnen zij via het concept van de 'omgekeerde vergelding' met elkaar in verband worden gebracht?

\section{Uitleiding}

Er is nog genoeg werk te verrichten ter verdere operationalisering van het zogeheten subsidiariteitsbeginsel. Herstelrecht en in het bijzonder een maximalistisch herstelrecht vormen daartoe niet de enige maar wel zeer krachtige katalysatoren. Het doel is om intentionele leedtoevoeging als reactie op misdaad zo veel mogelijk terug te dringen en te vervangen voor heilzamere alternatieven - met als ideaal aan de horizon nog steeds: vergelding van kwaad met goed (Claessen, 2010 en 2018). Uiteindelijk is hiervoor niets minder nodig dan een heuse bewustzijnsverandering.

13 Om de achterstand in de afhandeling van strafzaken die is ontstaan door de coronacrisis, weg te werken, heeft de Tweede Kamer op 21 september 2020 de motie van Van den Berge et al. aangenomen, die ertoe strekt om daarbij meer gebruik te maken van mediation (Kamerstukken II, 2020/21, 29279, nr. 612).

14 Zie www.sanctieuitvoering.nl/projectenlab/flexibel-op--en-afschalen-beveiliging-zorg-of-toe zicht/het-vonnisvoorstel.

15 Zie www.rechtspraak.nl/SiteCollectionDocuments/rechtstreeks-2019-01.pdf. 


\section{Literatuur}

Bianchi, T.H. (2008) Vergelding en berouw. Tijdschrift voor Herstelrecht, 8(3), 3-5.

Blad, J. (2005) Herstelrecht en subsidiariteit van strafrecht. Een pleidooi voor herstelrecht als operationalisering van subsidiariteit. Tijdschrift voor Herstelrecht, 5(2), 14-29.

Blad, J. (2009) Herstelrecht, eigenbelang en verantwoord burgerschap. Enkele reacties op het boek met dezelfde titel van Lode Walgrave. Tijdschrift voor Herstelrecht, 9(3), 51-64.

Blad, J. (2011) Het sanctieconcept van het herstelrecht. Sancties, (4), 232-250.

Claessen, J. (2010) Misdaad en straf. Een herbezinning op het strafrecht vanuit mystiek perspectief. Nijmegen: Wolf Legal Publishers.

Claessen, J. (2012) Pleidooi voor een ruimer strafbegrip of een strafrecht zonder straffixatie? Tijdschrift voor Herstelrecht, 12(4), 37-49.

Claessen, J. (2015) Wat we van onze zuiderburen kunnen leren: elektronische detentie in het strafrecht. Nieuwsbrief Strafrecht, 19(8), 588-590.

Claessen, J., J. Blad, G.J. Slump et al. (2018) Voorstel van Wet strekkende tot de invoering van herstelrechtvoorzieningen in het Wetboek van Strafvordering, inclusief Memorie van Toelichting. Oisterwijk: Wolf Legal Publishers.

Claessen, J. (2018) Martha Nussbaums Anger and Forgiveness: Over vergelding en vergeving en over woede en liefde. Tijdschrift voor Herstelrecht, 18(3), 14-32.

Claessen, J. (2019) Sanctionering van verkeersongevallen: Op het kruispunt van taakstraffen, verkeersdelicten en herstelrecht. Tijdschrift voor Herstelrecht, 19(3), 12-29.

Claessen, J. \& K. Roelofs (online) Herstelrecht(voorzieningen) en mediation in strafzaken. In: J. Boksem, P.A.M. Mevis, D.J.M.W. Paridaens et al. (red.), Handboek strafzaken (hoofdstuk 49). Wolters Kluwer (online te raadplegen).

Claessen, J. \& R. Djokarto (2020), Conflictbeslechting na misdaad bij de Marrons in Suriname: Mogelijke bruggen tussen de traditionele en moderne misdaadaanpak. Tijdschrift voor Herstelrecht, 20(2), 60-79.

Jongeneel, H. \& J. Claessen (2018) Naar een gevangenisstraf met behandeling. Nederlands Juristenblad, (19), 1364-1367.

Kaptein, H. (2008) Strafrecht als herstelrecht, vergelding als vergoeding. Tijdschrift voor Herstelrecht, 8(2), 47-54.

McCold, P. \& T. Wachtel (2003) In Pursuit of Paradigm: A Theory of Restorative Justice. International Institute for Restorative Practices 2003, te raadplegen via: www.iirp.edu/pdf/ paradigm.pdf .

Walgrave, L. (2008) Restorative Justice, Self-interest and Responsible Citizenship. London/ New York: Routledge.

Walgrave, L. (2009) Een maximalistische visie op herstelrecht. Tijdschrift voor Herstelrecht, 9(3), 19-38.

Walgrave, L. (2010) De maximalistische visie op herstelrecht onder vuur. Tijdschrift voor Herstelrecht, 10(1), 21-35.

Zehr, H. (2015) The Little Book of Restorative Justice. New York: Good Books. 